\title{
Mix Freeze group based Cooperative Learning Approach for Improving the Students Reading Comprehension at the first grade students of SMAN 1 Bontomarannu
}

\author{
Sujariati \\ yatisujar@gmail.com \\ Muhammadiyah University
}

\begin{abstract}
This research aimed to explain the improvement of the students' reading comprehension in terms of Literal Reading of the text dealing with main ideas and sequence of details and Creative Reading of the text dealing withcharacterization and conclusion. The researcher used a classroom action research (CAR) which was conducted in two cycles in which every cycle consisted of four meetings. The location of this research was taken at the first grade students of SMAN 1 Bontomarannu with a number of the subject were 35 students.

The research findings indicated that the application of SMAN 1 Bontomarannu, This strategy was improving the students' reading comprehension in terms ofLiteral reading and Creative reading of the text. It was proved by the mean score of cycle I was 60.7 . It was classified as fair then improved to be 73.36. It was classified as good in cycle II. They are higher than the mean score of diagnostic test namely 50.7 that classified as poor. Therefore there was the improvement of the students' reading comprehension in terms of Literal Reading of the text dealing with main ideas and sequence of details and Creative Reading of the text dealing withcharacterization and conclusion.
\end{abstract}

Keyword: cooperative learning; reading comprehension; literal reading; creative reading

\section{INTRODUCTION}

In language teaching, the phrases "reading skill" is often used to mean reading and understanding skill or reading comprehension. The sense in which reading skill is used where is taken as meaning trying to understand the oral message the people are conveying.

Today, to get information, people should read many kinds of book. Reading is a source of getting information. Actually, Reading is the easiest and the cheapest way to get information from the simple information to the more complex. In addition, the main important thing that the readers should have the ability to comprehend what they have read.

According to the English teacher in SMAN 1Bontomarannu, the lack of interest and motivation of the students to read especially at the first grade of SMA Negeri 1 Bonto Marannu may be caused by the methods and techniques or strategy that are not suitable with the students' need and the students' level. Of course it can be the serious problems for the students. As the result, they are not enthusiastic in learning English and it can influence their achievement such as in reading skill.

Based on the Diagnostic Test of SMA Negeri 1 Bonto Marannu, The data of students mean score is 50.7. They still have difficulties in understanding the text. The reading texts which were taught in the first grade Senior High School were descriptive, and narrative. Based on the observation results in the classroom and the interview results of the 
teachers and the students, the researcher finds that they have difficulties in narrative text (story text).

Some approaches had been applied to improve the students' readingcomprehension at the school, but those approaches are still weak, in the other words those approaches are not significant to improve the students' achievement in readingcomprehension, and the students still feel bored. The desire to read, as well as the capability to read, must be present for the successful recognition and analysis of text, especially the compleks reading text of language.

Pressley and Block (2002) also suggest that teachers can learn and teach by using strategy, how the strategies work and become betterin teaching students by applying the strategies to their own reading. Based on Kagan that one of strategy that can be used in teaching reading is a "Mix Freeze Group" method, whichis interesting and enjoyable for the students.

\section{The study}

The aim of the study was to investigate the use of Mix Freeze Group in Improving student's reading comprehension.

Two research questions posed to investigate these aims :

1. How does the Mix Freeze Group Strategy improve the students' reading comprehension in term of Literal reading Comprehension in the reading text at the first grade students of SMA Negeri 1 Bonto Marannu?

2. How does the Mix Freeze Group Strategy improve the students' reading comprehension in term of creative Reading comprehension in the reading text at the first grade students of SMA Negeri 1 Bonto Marannu?

\section{Literature Review}

Kagan (1994) DevelopedCooperative learning is called Mix Freeze Group Strategy to improve a class building and a type of structural peer interaction emphasizing positive human relationship in the classroom and uses to stimulation to train and develop reading related communication, language, and learning skill group.

Barbara, and Kathy (1998), said that Mix Freeze Group Strategy is classroom activities which the structures stress positive interpersonal peer relationship, equality, self esteem, and achievement. Students can work together by following the step to the structure, using material or content selected by the students them self or by the teacher. Basicly this strategy has structural appcoach to cooperative learning and make the students are interested the class building teaching learning process.

Barbara, and Kathy (1998), said that Mix Freeze Group Strategy is classroom activities which the structures stress positive interpersonal peer relationship, equality, self esteem, and achievement. Students can work together by following the step to the structure, using material or content selected by the students them self or by the teacher. Basicly this strategy has structural appcoach to cooperative learning and make the students are interested the class building teaching learning process.

\section{Concept Of Mix, Freeze Group Strategy}

Kagan has developed Mix Freeze Group" structures" which may be thought of as steps to classroom activities with structural approach various aims, such us: (1) Building team 
spirit and positive relationships among students; (2) Information sharing; (3) Critical thinking; (4) Communication skill; (5) And mastery (learning/remembering) of specified material

\section{The History Of Mix Freeze Group Strategy}

Mix Freeze Group Strategy is one the types of cooperative learning strategy, it was proposed by Kagan at California University in 1994 which is the most edition to his teory and has been met with more resistance than others type of cooperative learning, it also has been implemented in Japan by Jane Joritz-Nakagawa (Aichi University of Education) in 1998. ( Kagan, $1994: 12$ ).

This strategy briefly describes and discusses Spencer kagan's approach to cooperative learning Mix Freeze Group. Mix Freeze Group Strategy in cooperative learning is a type of structured peer interaction emphazing positive human relationships, colaboration between peers, active learning, academic achivement, equal participant, and equal status of students in the classroom. it can be used to teach any subject matter, whether that be foreign languages, math, social studies, etc.

\section{Characteristic Of Mix, Freeze Group Strategy}

According to Candler 1998, The Characteristic of Mix Freeze Group are:

a. Finding more vocabulary

Mix Freeze Group Strategy can apply in many subject materials such as reading text, listening and speaking group, in content mastery it sould be guided and know more vocabulary, specifically in reading text the students read and understand the words means and interprate the text content. This strategy guided us to read more vocabulary and share with the partner to solve the problem given.

b. Have many sensory ( sigh,sound, brain, tought, ) to notice and reach the word means. This strategy involved our sigh, our mind, and our though to respons the material. We have to speak with our partner, share with our group and read and think the text carefully by using our own sigh and tought. To reach the materials aims the students must have sensory in other that the problem being solved.

c. Interested in reading text, Story and Dialoque

This strategy can apply in reading, speaking and listening. This strategy like enjoy to read and understanding or listen what we talk about. The students will enjoy read the text, story or listen the dialogue because they are in freeze and they can share their ideas and thinking.

d. Expresses students's self and tinking Because this strategy involved the students' mind and their power so they must be active in learning process, the results of the activity the students expreses their self to through the structure and also expresse their thinking what they have read and tell their team groups.

e. Involved interaction and communication

Absolutely this strategy involved interaction to materials, students and other groups. They dont do it by it self but they need comunicate the problem to their group to share their ideas and tinking, they also need discussion each other what have they read of the text to answer the question given. 
The Principle Of Mix Freeze Group Strategy(Kagan, 1994. Kagan \& Mc Carty, 1995.)

a. Greater Comprehensible input. Student adjust their speech to the level of their partner because they are working together.

b. Negotiate meaning. Student has the opportunity to adjust their language output to make sure they understand each other.

c. Lower Affective filter. Whereas it is frightening to speak out in front of the whole class, it is easy for a student to read, talk and to write with a supportive team mate.

d. Peer Support. Student encourages and support each other in team works language use.

e. Enhance Motivation. Because the structures are engaging interaction sequences, and students need to understand each other, there is a high motivation to speak, write and to read for understanding.

f. Greater language Use. Using a pair structure such as time pair share, it takes two minutes to give every student opportunity to produce language.

\section{The Structural Approach To Mix Freeze Group Strategy}

a. Grouping of Students:

1) The researcher grouping the students by saying Mix for the first time and the students will walk around the classroom to find a partner be a group.

2) The students will have time to read and share their ideas to answer the questions on the reading text.

3) The researcher grouping again the students by telling Mix to find more members into their group, than freeze them again in giving them time to read and share their ideas to each other and answer the next question. It will continue until the group has formed in four or five group.

4) The students are given time again by the researcher to share about what have they read and make a conclusion, then collect their task and then telling what have the student read in front of the class.

b. Materials Needed:

1) Materials are necessary for reading skill, story text or dialogue teks.

2) The researcher should prepared questions that can be answered on a paper.

c. Direction:

1) "Mix" Student will walk around the room in all direction and areas.

2) The student will get lost or found

3) The researcher swill yell 'Freeze'!

4) While students are frozen, the researcher gives time to the students to read and share each other to answer the question.

\section{Effective Small Group Teaching}

Effective small group teaching is much more challenge task than is often realized. It is much more difficult for students to discuss coherently, to question, and think the underlying themes are getting students to talk to each other as well as a tutor and getting students to think. We than explore the skill required by students as well as a tutor if small group teaching to be effective an ending it with guidelines for preparing for small group teaching and some suggestions for evaluating your small group teaching. 
ELT Worldwide Vol 5 No 2 (2018)

Sujariati : Mix freeze group based ...

\section{The Concept of Reading Comprehension}

Reading comprehension is a complex process in which the readers use mental content to obtain the meaning from written materials. It means that reading is a complex process in which the reader is supposed to recognize the meaning of printed words; it can be that reading comprehension is a capability to understand of paragraphs, the ideas of one passage. In other words, reading comprehension is the act of what the eyes have been in finding information from the reading passage both explicitly, implicitly, and ability to describe the conclusion.

Smith and Robinson (2007:7)state reading comprehension is the complex process in which the readers use mental content to obtain the meaning from written materials. It means that reading is a complex process in which the reader is supposed to recognize the meaning of printed words; it can be that reading comprehension is a capability to understand of paragraphs, the ideas of one passage

\section{Levels of Reading Comprehension}

The levels of Reading Comprehension according to Smith (1977:107) are Literal reading, Interpretative reading, Critical reading, and Creative reading.

\section{Literal Reading}

Literal reading refers to the acquisition of the meaning of ideas or information that is explicitly stated in the text. Some specific reading skill at the literal level of comprehension is identifying specific information (main ideas) which is consist of time, date, place, and sequencing event that consist of conflict and plot.

1) Identifying Specific Information (Main Ideas)

This reading requires one to focus his attention only on one or some particular information or detail which he need form a text; the rest of it may not be read anymore. That information may be main ideas, a name, a date, a scientific term, or a place or just anything, the search for which motivates the person to read. In looking for detail, the reader must look for signals in the environment of the needed information it self.

2) Sequencing Events

Meaningful reading results from the reader's ability to follow the flow of thought of the writer. It is because any discourse is made up of words and sentences which are not only grammatically linked to one another but also related to conflict and plot, the basic is dramatic conflict. For convinience, we can place the dramatic conflict that found in short stories in three categories. Those are:

a) First is the phisical or Elemental Conflict. Here we usually find a person or thing in conflict with nature. In such a story we may go through the struggles of a man climbing a mountain, a woman fighting to survive in a cycloun, etc. The principal appeal of kind of story is almost wholly to the emotions of the reader.

b) The second types of dramatic conflict is Social conflict. In this type of one person against another: two women seeking to marry the same man, two men competing for a job, a detective pitted against a criminal, a child in conflict with his parents, etc. The principal of the conflict happen between the actor to another actor.

c) The third type of conflict is Internal or Psychological conflict. Here we find a person struggling against with him or her self, his conscience, his guilt, or simple trying to decide what he's going to do. In such a story we may see an honest man but poor, a woman struggling with the consequence of a lie she's told, or unwanted pregnant a 
girl trying to decide whether to have an abortion, place her child up for adoption, or raise him alone, etc. The principal of this conflict telling about anxious, doubt, uncertainly. ( Edward H. Jones Jr 1987: 30 ).

\section{Creative Reading}

According to Marshall (1998), Creative reading involves going beyond the material presented by the author; Creative reading consists of:

a) Ideas

b) Imagination and solution

c) Character

d) Conclusion

According to Marshall (1998), creative reading is the readers'understood to involve the more predictable and manageable set of skills. The ability to accurately represent the argument in the assigned reading. While we do think the ability to accurately represent the ideas of other writer is of central importance. We also think that it is not just away to better comprehend the ideas of others, but can also be a creative process for developing and then better understanding your own ideas as they relate to the ideas of others. Creative readers make sure that they know what the author is saying at the same time, devoting their energies to actively constructing an otherwise implicit relationship between ideas, even, and context. That is, creative reading involves imagining how and why different position represented in the text might be made to relate to each other.

Creative reading also means using your own experience and knowledge of the world to critically examine the ideas presented in the text. By considering an authors' ideas in new context, you can find your ways to develope your own contribution to the public debate which this reading text (Mirriam \& Marshal 1998).

\section{There are many ways to do a creative reading, those are:}

a) You can consider a connections between the authors' ideas and your experiences.

b) You can think about how the authors ' ideas might work in another context.

c) You can establish connection between some of authors as a way of developing your own position.

When you read and respond what you have read in this ways, you turn the work of reading into creative, self-directed process that helps you develop new ways of tinking about understanding the world.( Wells \& Canfield, 1997 )

\section{The Characteristic of Creative Reading}

a) Characterization. Characterization is the depicting of clear images of a person. There are two methods of characterization: the dramatic and analytic. In the dramatic we form our opinions of the characters from what they do and say, from their environment, and from what other characters think of them. In the analytic method the author comments upon the character, explaining their motives, their appearnce, and their thoughts. The principal of characterization is find out the characters of the actor in the story, and what do you think each character felt about the event which one good and bad you think. You can also characterize the story is the story good or bad for your life or is there any corelation your experiencess with the story. Also thinking that is the story real or not, is the story can giving good influencess for the reader who had read it, is the story giving good improvement habituality and good behavior in the life. (Edward H. Jones Jr 1987:34) 


\section{METHOD}

\section{Research Design}

This research applied classroom action research (CAR). Two instruments used by the researcher. Those were classroom observation and reading test. The data from observation would be analyzed qualitatively and quantitatively. The research divided in two cycles with each cycle consist of five steps. Cycle 1 consist of planning, action, observation, evaluation and reflection. cycle II was the same with cycle I which conducted four times meeting.

\section{Research Variable and Indicator}

The research has two kinds of variables namely independent variable and dependent variable.

Independent variable of the research was the use of Mix Freeze group strategy.

Dependent variable was increasing the students' reading comprehension.

The indicators were: Literal reading consist of the main ideas and sequence event, and creative reading consist of characterization and conclusion.

\section{Research Instrument}

Oobservation sheet aims to measure the improvement and effectiveness of students.

Reading test aims to find out the students result and response of teaching learning process through the use of Mix Freeze Group Strategy.

\section{Participant}

The subjects of this research were the first - grade students of the class X8 in

2012-2013 academic years.

\section{The Procedure for Collecting Data}

1. The data sources got from:

a) Students gave data about their participation, responses and their comprehension in reading text through Mix freeze group Strategy

b) Teacher as the monitor of the implementation of mix freeze group teaching and students' participation, response, and competence the text.

2. The data analysis which was received consisted of

a) The findings of the study as quantitative data

b) The findings of observation as qualitative

The data from cycle 1 and cycle II had been analyzed in the following steps:

1. Scoring the students' answer of the test, the researcher used formula.

$$
\text { Student's Score }=\frac{\text { Total Score }}{\text { Maximum }} \times 100
$$

Scored the students answer based on the following criteria which supported by Walters: 1992. 
Tabel.1.1 Literal reading dealing main ideas

\begin{tabular}{lc}
\multicolumn{1}{c}{ Indicators } & Score \\
\hline $\begin{array}{l}\text { The Student uses all relevant information stated directly in the text to answer } \\
\text { the questions. }\end{array}$ & 40 \\
\hline $\begin{array}{l}\text { The Student uses most relevant information stated directly in the text to answer } \\
\text { the questions. }\end{array}$ & 30 \\
\hline $\begin{array}{l}\text { The Student uses some relevant information stated directly in the text to answer } \\
\text { the question. }\end{array}$ & 20 \\
\hline $\begin{array}{l}\text { The Student uses little or no relevant information stated directly in the text to } \\
\text { answer the questions. }\end{array}$ & 10 \\
\hline
\end{tabular}

Tabel 1.2. Literal reading dealing Sequence event

Indicators Score

Student tells all the sequence relevant information directly in the text to answer the questions.

Student tells most the sequence relevant information directly in the text to answer the questions.

Student tells some sequence relevant information directly in the text to answer the question.

Student tells little or no sequence relevant information directly in the text to answer the questions.

Tabel 1.3 Creative reading dealing characterization Indicators

The Student explains all the characters, telling the story what would like be

The Student explains most of the characters, telling the story what would like

The Student explains some of the characters, telling little of the story

The Student does not explains the charaters, telling just little the story

Tabel 1.4. Creative reading dealing with the conclusion

\begin{tabular}{ll}
\hline \multicolumn{1}{c}{ Indicators } & Score \\
\hline Student explains all the story and make a very good conclusion & 40 \\
\hline Student explains most of the story and make a good conclusion & 30 \\
\hline Student explains some of the stories and make fairly conclusion & 20 \\
\hline The Student does not explain all the story and does not make a conclusion & 10 \\
\hline
\end{tabular}


2. Calculated the mean score of the students' reading test by using the following formula.

$$
\bar{X}=\frac{\sum \mathbf{X}}{\mathbf{N}}
$$

Where

$\overline{\mathbf{X}} \quad=$ The Mean score

$\sum \mathrm{X}=$ The Total score

$\mathrm{N} \quad=$ The Total number of Students.

(Gay, 1981:298)

3. Classifying score of students reading comprehension

Tabel.1.5 Classifying score of students reading comprehension

\begin{tabular}{ccc}
\hline No & Classification & Range \\
\hline 1 & Excellent & $96-100$ \\
\hline 2 & Very good & $86-95$ \\
\hline 3 & Good & $76-85$ \\
\hline 4 & Fairly Good & $66-75$ \\
\hline 5 & Fairly & $56-65$ \\
\hline 6 & Poor & $36-55$ \\
\hline 7 & Very Poor & $0.0-35$ \\
\hline
\end{tabular}

4. The data was taken from the observation, the researcher identifies through the students' participation in teaching and learning process based on the criteria :

\section{Tabel 1.6. The Students' Active Participation}

\begin{tabular}{cll} 
No & $\begin{array}{c}\text { The students' active } \\
\text { participation }\end{array}$ & \multicolumn{1}{c}{ Indicator } \\
\hline 4 & Very Active & Students respond to the material very actively \\
\hline 3 & Active & Students respond to the material actively \\
\hline 2 & Fairly Active & Students respond the material ones or twice \\
\hline 1 & Not Active & $\begin{array}{l}\text { Students sit down during the activity without } \\
\text { doing something. }\end{array}$ \\
\hline
\end{tabular}

Percentage of the students' participation through the following formula:

$$
\mathrm{P}=\frac{\mathrm{FQ}}{4 \mathrm{xN}} \mathrm{x} 100
$$

Where:

$\mathrm{P} \quad=$ Rate Percentage

$\mathrm{F} \quad=$ Frequency of the Correct Answer

$\mathrm{N}=$ The Total Number of Subject.

$4=$ The Max Score 


\section{Research Finding}

The result of this research based on the research questions as follows :

Table 1.7.. The Improvement of the Students' Literal Reading of The Text

\begin{tabular}{lcc}
\hline \multirow{2}{*}{ Indicators } & Cycle 1 & Cycle 2 \\
& & \\
\hline Main Ideas & 57.06 & 68.68 \\
\hline Sequnces Details & 58.46 & 68.82 \\
\hline Total Score & 115.52 & 139.87 \\
\hline Mean Score & $\mathbf{5 7 . 7 6}$ & $\mathbf{6 9 . 9 3}$ \\
\hline
\end{tabular}

The table above indicates the mean score literal reading in cycle one it indicates (57.76). And for cycle II it indicates (69.93). It prooved that there is significant improvement from cycle 1 and to cyle II

To see the improvement of the students' literal reading of the text, the following chart is presented:

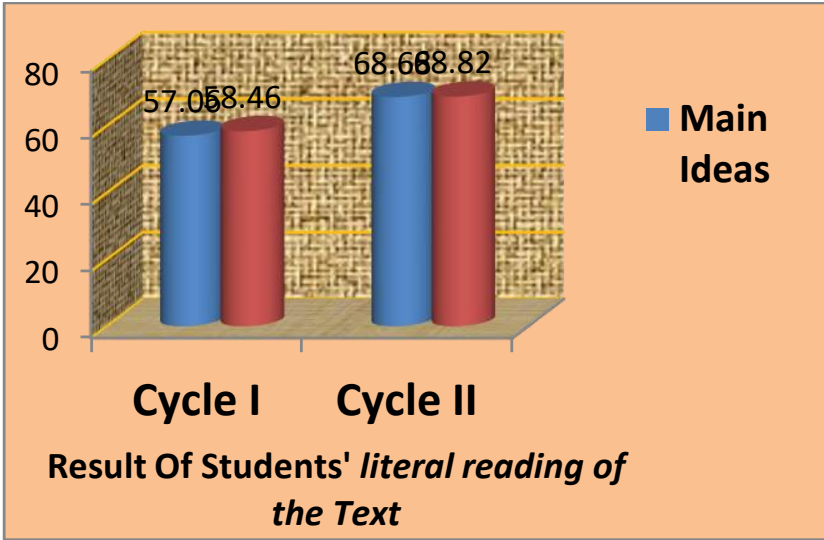

Figure 1: The Improvement of the Students' Literal Reading of The Text

The table above shows that there is a improvement of main ideas and sequences details from cycle 1 to cycle II. Where if we calculated of main ideas from cycle 1 is $20 \%$. and the improvement of sequences from cycle 1 to cycle II is $17.7 \%$.

\section{The Improvement of the Students' Creative reading.}

The improvement of the students' reading comprehension of the text, which focused on Creative Reading which consists of characterization and conclusion as indicators in X8 SMAN 1 BONTO MARANNU as result of the students' assessment of Cycle I and Cycle II can be seen clearly in the following table :

Table 1.7. The Improvement of the Students' Creative Reading of The Text 


\begin{tabular}{ccc}
\hline Indicators & Cycle 1 & Cycle 2 \\
\hline Characterization & 61.50 & 74.04 \\
\hline Conclusion & 65.71 & 81.91 \\
\hline Total Score & 127.21 & 155.95 \\
\hline Mean Score & $\mathbf{6 3 . 6}$ & $\mathbf{7 7 . 9 7}$ \\
\hline
\end{tabular}

The table above indicates the mean score of creative reading in cycle one it indicates (63.6). and for cycle two it indicates (77.97). it is proof that there is significant improvement from diagnostic test without using a method to cycle 1 and cyle II which is used method.

To see the percentage score improvement of the students' creative reading of the text following chart is presented

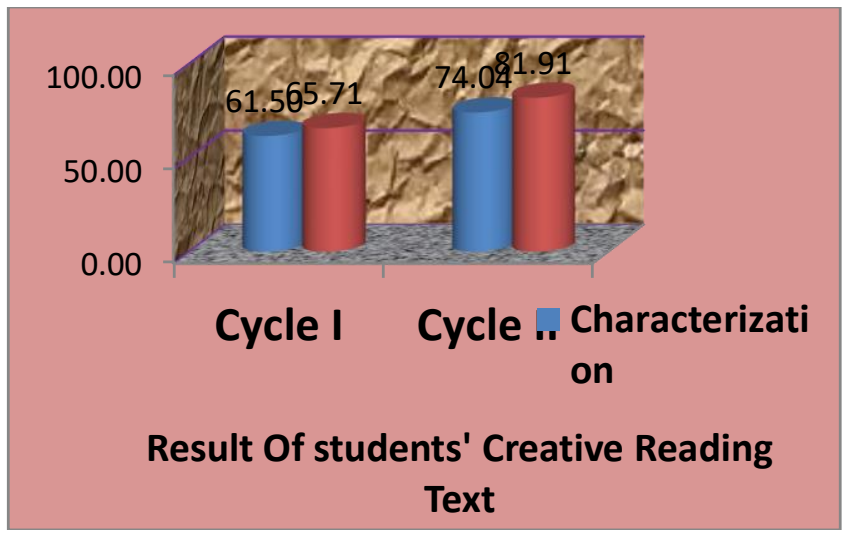

Figure 2: The Improvement of the Students' Creative Reading of The Text

The table above shows that there is an improvement of characterization and conclusion from cycle 1 to cycle II. Where if we calculated the characterization from cycle 1 to cycle II is $20 \%$. and the improvement of coclusion from cycle 1 to cycle II is $33 \%$

\section{The Improvement of the Students' Reading Comprehension of The Text.}

The improvement of the students' reading comprehension of the text, which focused on Specific Information and Creative Reading as indicators in X8 SMAN 1 BONTO MARANNU as result of the students' assessment of Diagnostic- Test, Cycle I and Cycle II can be seen clearly in the following table : 
Table 1.8. The Improvement of the Students' Reading Comprehension of The Text

\begin{tabular}{lccc}
\hline Variables & $\begin{array}{c}\text { Diagnostic } \\
\text { Test }\end{array}$ & Cycle 1 & Cycle 2 \\
\hline Specific Information & 48.14 & 57.76 & 68.75 \\
\hline Creative Reading & 53.24 & 63.6 & 77.97 \\
\hline Total Score & 101.38 & 121.36 & 146.72 \\
\hline Mean Score & $\mathbf{5 0 . 7}$ & $\mathbf{6 0 . 7}$ & $\mathbf{7 3 . 3 6}$ \\
\hline
\end{tabular}

What the table above indicates the mean score of reading comprehension in diagnostic test (50.7), for cycle one it indicates (60.7). And for cycle two it indicates (73.36). it is proof that there is a significant improvement from diagnostic test without using a method.

To see y the improvement of the students' reading comprehension

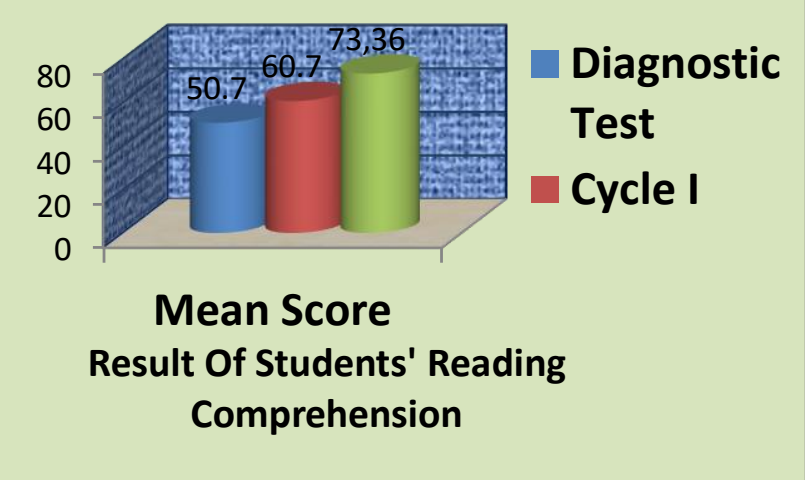

Figure 3: The Improvement of the Students' Reading Comprehension

The chart above shows very clearly that there is improvement of the students' reading comprehension from diagnostic test to cycle I and cycle 1 to cycle II where when we calculated the improvement from diagnostic test to cycle 1 is $19 \%$, and improvement from cycle 1 to cycle II is $20 \%$ and the improvement from diagnostic test to cycle II is $44 \%$

\section{The Result of the Students' Activeness in Learning Process.}

The result of observation of the students' activeness in teaching and learning process during eight meetings was taken by the observer through observation sheet. It could be seen clearly through the following table.

Table 1.8. The Result of the Students' Activeness in Each Meeting

\begin{tabular}{|c|c|c|c|c|c|c|}
\hline \multirow{2}{*}{ Cycle } & \multicolumn{4}{|c|}{ Meetings } & \multirow{2}{*}{$\begin{array}{l}\text { Average } \\
\text { Score }\end{array}$} & \multirow{2}{*}{$\begin{array}{c}\text { Improv } \\
\text { ement }\end{array}$} \\
\hline & I & II & III & IV & & \\
\hline I & $\begin{array}{c}68.57 \\
\%\end{array}$ & $\begin{array}{c}62.14 \\
\%\end{array}$ & $70 \%$ & $79.28 \%$ & $69.99 \%$ & \\
\hline II & $\begin{array}{c}73.57 \\
\%\end{array}$ & $80 \%$ & $\begin{array}{c}77.85 \\
\%\end{array}$ & $81.42 \%$ & $78.21 \%$ & $11.74 \%$ \\
\hline
\end{tabular}


The table above explains about the average of the students' activeness in the teaching and learning process through observation sheet by the observer. The table above shows the process the students' activity in each meeting. The percentages of the cycle I from the first meeting to the fourth meeting are $68.57 \%, 62.14 \%, 70 \%$, and $79.28 \%$. Moreover, from the first meeting to the fourth meeting is $73.57 \%, 80 \%, 77.85 \%$ and 81.42 . To see the improvement of the students' activeness, the following chart is presented:

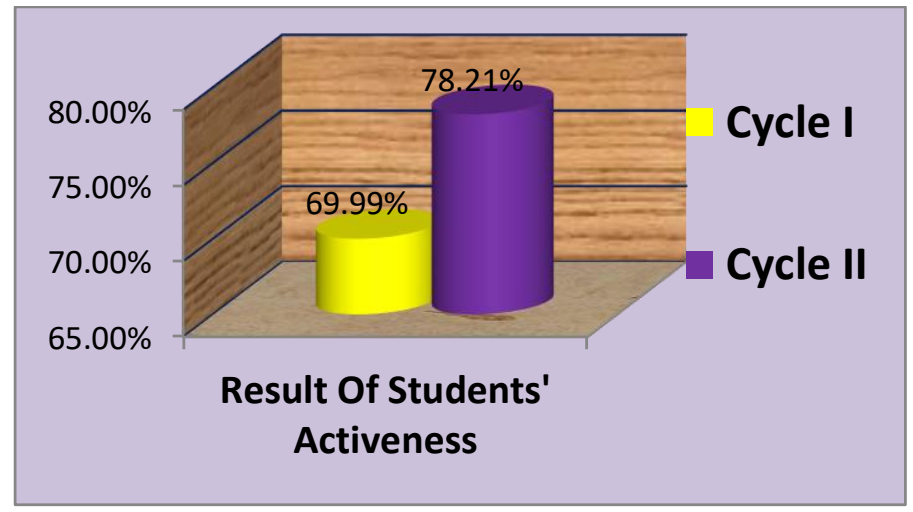

Figure 7: The Students' Observation in learning Reading Skills.

The chart above presented the students' situation during reading a text in teaching and learning process. From the graphic, it is known that there is a changing of students' situation in learning reading is $69.99 \%$ and the changed to be $78.21 \%$ with improvement $11.7 \%$.

\section{CONCLUSION}

The use of Mix Freeze group Teaching Strategy in presenting the reading comprehension material at the X8 class students' of SMANegeri1 Bonto Marannu improves the students' achievement significantly. The findings indicate that the mean score of the test in cycle two is greater than the cycle I. The use of Mix Freeze Group in Teaching can improve the students' reading comprehension in finding the Specific information of the text dealing with main ideas and sequence events. The use of Mix Freeze Group Teaching Strategy can improve the students' reading comprehension regarding the Creative reading of the text dealing in Characterization and conclusion at the students' of X8 class SMA Negeri 1 Bonto marannu. The Mix Freeze Group Teaching Strategy is very enjoyable and interesting for students so the students more active and enthusiastic to read so Mix Freeze Group Strategy can improve the student activeness and reading comprehension at the $\mathrm{X} 8$ grade students of SMAN 1 Bontomarannu.

\section{REFERENCES}

Barbara \& Kathy1998.kathy@ auecc.aichi-edu.ac.jp.andwww.KaganOnline.com Brown, George and Atkins, Madeline; 1987. Effective Teaching In Higher education Bligh 1980 \& Jaques 1984. Reading Strategy vocabulary work grouping (Small Group) retrieved $21^{\text {th }}$ October 2011. 
Barners in Palaloi. (1999) Instructional Reading Strategy: DRTA (Directed Reading Thinking Aktivity) retrieved October $21^{\text {th }} 1999$

Dark and Silberstain. 2011 http://www.lextutor.ca/cv/webthesis/Thesis8.html. Accessed on July 20, 2011

Depdikbud in Herlis (2011).Buku Laporan Pendidikan Menengah Umum Tingkat pertama. Jakarta. Dikbud

Dubin and Taveggia 1968; Argyle 1983. Effective small group method

Edward H. Jones Jr; 1987. Short stories, Elcamino Collage.

Goldschmid,.http://www.educatiosn.com/reference/article/constructivism/. Accessed on July 12, 2011.

Gay, L. R. 1981. Educational Research. Competencies for Analysis and Aplication. Second edition. London. Charles Emaril Publishing Company.

JALT, Japan Association for Language Teaching,(Kluge et al,1999;Poel 1994)

Kagan,Spencer1994.http://www.kaganonline.com/KaganClub/FreeArticles/ASK17.html

Kagan, Spencer \& McCarty, 1995. http://www.goartyonline.com/Articles

Kagan, Spencer . 1994. Cooperative Learning 27134 Paseo Espada.

Kulik 1979; Jaques 1984 and Bligh 1980, Small group method.

Leipsing. (2001:39).Teaching reading. Ahandbook.Newyork.St Martin Press.

Laura. Candler, $1998 \sim$ Teaching Resources www.lauracandler.com

McCarty. http://iteslj.org/Articles/McCarthy-Reading.html. Accessed on August 02, 2011

http:// www.indiana.edul/-1517/Creative Reading .htm of ST, Miller Schmitt From http://www.scrib.com on $21^{\text {th }}$ September 1986.

Mirriam \& Marshal. http://www.Mirriam-reading.html. Accessed on october 1998.

Morever \& Eddle Williams. (1984:15). Teaching reading in early Application England. London: Pitman and Sons Ltd.

Morever, (1984:103), The purposes Reading Strategy of language, London.

Nuttal, 2000. The purpose enhance knowledgeof language being read. New York Cambrige University.

Presley \& Block. (2002) Teaching Reading Comprehension Tostruggling And At-Risk Readers: Strategies That Work

Richard, J. Miller S.T. 1986. Approach and method in Language Teaching. A Creative Reading and Analysis. New York: Cambridge university Press.

Reading Strategy of the month ( n.d) vocabulary work Box (Small Group) retrieved $21^{\text {th }}$ October 2011.

Ramirez in Ismail,(1999) Membaca Strategy PengantardanTehniknya. Jakarta. Depdikbud.

Simanjuntak,Eskey in Harimin Yasin. M. 1998, Improving the Students' Reading Comprehension through REDWD Strategy. Thesis: Makasssar. Unismuh Makassar.

Smith and Robinson. 2007. Reading in a Foreign Language. London, Longman pp 181198.

Smith, N.B 1977. Reading Instruction for Today's Children. Boston; Practice-Hall, inc.

Sudjana, Nana. Bkk. 2010. Penelitian dan Penilaian Pendidikan. Cet vi. Bandung : Sinar Baru Algensindo 
ELT Worldwide Vol 5 No 2 (2018)

Sudiyono, A. 2005. Pengantar Statitiska Pendidikan. Jakarta:Pt. Raja Grafindo Persada.

TeacherVision.http://WWW.teachervision.fen.com/skill-buider/reading comprentsion/48611.html. Accessed on August 10, 2011

Thinker and McCollough, Reading Ability the first edition ( 1975;9)

Wells, H.C. Canfield, 1997. 100 Ways to Enhance Self confidence

Walters;1992. How to write a good conclusion essay. Vol.1 Retrieved from http:// Collage livetext.com.doc.on November 242011 